\title{
HEALTHCARE IN UKRAINE DURING THE EPIDEMIC: DIFFICULTIES, CHALLENGES AND SOLUTIONS
}

D0I: 10.36740/WLek202105139

\author{
Anna R. Ivats-Chabina' ${ }^{1}$, Olena L. Korolchuk ${ }^{1,2}$, Alexandr Yu. Kachur ${ }^{3}$, Vladyslav A. Smiianov ${ }^{4}$ \\ ${ }^{1}$ UZHHOROD NATIONAL UNIVERSITY, UZHHOROD, UKRAINE \\ ${ }^{2}$ NATIONAL ACADEMY FOR PUBLIC ADMINISTRATION UNDER THE PRESIDENT OF UKRAINE, KYIV, UKRAINE \\ ${ }^{3}$ INTERNATIONAL EUROPEAN UNIVERSITY, KYIV, UKRAINE \\ ${ }^{4}$ SUMY STATE UNIVERSITY, SUMY, UKRAINE
}

\begin{abstract}
The aim: Of this research was to investigate the impact of quarantine restrictions on the health care system in Ukraine, quality of providing and accessibility of health care services for population during quarantine; analyze the influence of economic and social outcomes of epidemy on state of health care.

Materials and methods: For this paper was made a retrospective analysis of COVID-19 morbidity statistics, economic indicators and governmental decrees aimed at resolving the problem of the spreading of coronavirus and ensuring the proper work of medical institutions at all levels of health care. This work includes analysis of data for the period since the beginning of quarantine on the territory of Ukraine in March 2020 till present time.

Conclusions: The complexity of the socio-political and economic situation in Ukraine and the conduct of hostilities in the east of the country have significantly complicated the fight against the spread of coronavirus in the country. Negative changes in the indicators of hospital security were observed both at the secondary level - treatment of patients with COVID-19, and the primary level - primary contact with the patient, primary care, prevention measures. In the long run, this will have significant implications for the individual health of those who have not been able to receive quality care, as well as for public health in general.
\end{abstract}

KEY WORDS: public health, primary health care, healtchcare during quarantine, social and economic impact of pandemia

Wiad Lek. 2021;74(5):1256-1261

\section{INTRODUCTION}

The Covid-19 epidemic has negatively affected all countries of the world, without exception, all people and nations; the final consequences of the pandemic will be studied for many more years.

It should be noted that the majority of health care systems, despite the scale of the negative impact, by joint efforts, with different losses, effectively cope with the problem of the infection. But Covid-19 has brought the whole world into a state of life and activity in new, unpredictable quarantine conditions. The same situation is in Ukraine.

\section{THE AIM}

This research aimed to investigate the impact of quarantine restrictions on the health care system in Ukraine, quality of providing and accessibility of health care services for the population during quarantine; analyze the influence of economic and social outcomes of epidemy on the state of health care.

\section{MATERIALS AND METHODS}

Materials and methods for this paper was made a retrospective analysis of COVID-19 morbidity statistics, economic indicators and governmental decrees aimed at resolving the problem of the spreading of coronavirus and ensuring the proper work of medical institutions at all levels of health care. This work includes analysis of data for the period since the beginning of quarantine on the territory of Ukraine in March 2020 till present time.

\section{REVIEW AND DISCUSSION}

To see the real picture of the development of events in the modern realities of the "covid world", let's look at the conditions for the development of healthcare in Ukraine in recent years. It is important that in recent years, the national health care system has begun to transform into a modern system that can, in the future, provide conditions for maintaining and improving the health of the population. But these are the first steps, the real results of which we will understand later.

It should be noted that the nationwide conditions of the implementation of really effective timely transformations of the health care sphere in Ukraine were quite difficult, because the country and the nation was and still is emerging from a difficult situation of complex consequences, a combination of the impact of many diverse factors - crises in various spheres of state activity that lasted for years and were not effectively resolved for decades. 
For example, to the main negative transformations that Ukraine has been effectively but very slowly overcoming over the past 10 years, associated with the polymorphic influence of risks, the researchers include: imperfect infrastructure, economic imbalances and instability; inconsistency of policies, dissimilarity of decisions and practices; inconsistency in the making and ineffective implementation of managerial decisions that overload the economic, social and humanitarian spheres; the failure of many sectors/spheres of state life as a result of many years of lengthy, redirected incomplete reforms; complicated demographic situation and aging of the population, deterioration of health indicators and, accordingly, reproduction; impoverishment of the population and growth of social imbalances; growth of the emigration of the country's intellectual and labor potential.

All this is aggravated by the hostilities in the east of the country, the Joint Forces operation, and in turn leads to the following consequences: intensification of forced migration, the emergence of two new social groups: internally displaced persons and combatants, which require attention and assistance, especially in the field of health care; destruction of infrastructure and territories; the emergence of new Ukrainian health problems associated with both combat injuries and mental health problems, both for combatants and people who are temporarily or permanently in the zone of operations of the Joint Forces; an increase in the number of abuse and dependence on alcohol, drugs, antisocial behavior; the intensity of negativization of the social climate, the growth of aggressiveness in society etc. [1]

Such a situation dragged on for years has complicated the management processes, creating the vulnerability of the state and the nation, reducing the potential for resilience to risks in general, worsening the health of the nation with a known overload on the imperfect structure of the health care system.

We must note that there were also positive shifts: Ukraine's new position as a geopolitical partner (for the first time in its recent history) - Ukraine received significant support from the world community, influencing the world; - accession to the EU is a European choice, which activated the Europeanization of society and the state, a systematic renewal of values, the assimilation and implementation of European norms and standards of life, the introduction of European norms and standards of public administration and local self-government, first of all, through the adaptation of the legislative framework to European legal paradigm, increasing European political and expert assistance; - a real movement towards the implementation and completion of the necessary systemic reforms, about 60 , the implementation of which determines the future, the positive results of which may appear among the citizens of Ukraine only years later; - the development of civil society and consciousness - the population becomes an active subject, influencing the authorities and a full-fledged initiator and participant of transformations, respectively, with the activation of local self-government and general, partner management, and the like.
However, the problematic issues of the growing popularity of democratic principles of governance remain open; exacerbation of issues related to the freedom of the individual, the protection and strengthening of his rights, and, at the same time, the restriction of his rights and freedoms by generally recognized and accepted rules; ensuring governance in Ukraine in accordance with citizens' requests and increasing citizens' participation in solving economic, political, cultural and other issues, developing self-government and joint management; ensuring the activity of the process of Ukrainian society entering the information era, where the role of information and telecommunications has increased, network structures have emerged, the virtual world exists and develops, inevitably affects reality with the formation of e-government and self-government, e-democracy, network management structures, national intelligence, expert communities etc; solving issues related to the development of effective anti-crisis management. [1]

Ukraine fell into a global crisis - the Covid-19 epidemic, having the above problems and prospects. Thus, in Ukraine on March 3, 2020, the first case of infection with the coronavirus COVID-19 was recorded, then the detection of coronavirus began to be reported in other areas. March 12, was introduced first quarantine measures, while the coronavirus is already a few weeks actively raged in Europe. Through active dissemination of the disease, some Ukrainian regions imposed strict restrictions. On February 20, Ukraine evacuated its citizens from China - 45 people (from the province of Wuhan, from where the virus spread) and 27 citizens of foreign countries, who were sent for observation. When the pandemic in Europe reached its peak and workers and tourists rushed to return in Ukraine, for whom antiCovid measures were not prepared in time, plus no mechanisms of coercion and almost no limit for people and those, with whom they were contacting. The population also did not show sufficient caution and often neglected the necessary protection measures.

In difficult times in Ukraine, the conscious part of the population has traditionally become more active. Volunteers were and are helping to provide Ukrainian doctors with protective equipment and disinfectants, delivering food to pensioners, sewing fabric masks, because there are simply not enought medical ones in the country, drivers bring doctors to work. Members of large business have also joined in to help. However, at the same time, in Ukraine there is a huge number of unconscious people, who openly ignore all quarantine requirements, endangering not only themselves, but also those around them, adding jobs to the already overburdened doctors.

Note that the response options and anti-crisis measures to COVID-19 outbreaks in different regions of Ukraine vary and depend on many factors, including the region's capabilities, direct coordination of response measures by regional authorities, especially with the existing regional asymmetry. In addition, the imperfections in health care legislation that remain today are becoming barriers to the implementation of some initiatives. For example, we consider it as a positive point that in several regions (such 
as Chernivtsi, Volyn regions) during the quarantine the previously abandoned premises of the laboratory centers of the Ministry of Health were modernized. It should be emphasized that the lack of laboratories, equipment, inventory and tools, professional staff and means of their protection was one of the important factors of unpreparedness for a quality response to the problem of Covid-19, which the country has dealt with effectively. It is believed that Ukraine, as all big decentralized countries, also faces significant challenges in coordinating its work - regional and local governments are responsible for key aspects of health care, health care management, social services and economic development. As these responsibilities are tasks of different levels of government, coordinating efforts in times of risk and threat is extremely important. At the same time, regional and local authorities may have different strategic priorities and opportunities, given the existing regional asymmetry. Intergovernmental coordination is a constant focus on strategies and policies in such situations and is a critical element in ensuring the quality and timeliness of responses. In Ukraine, with varying exacerbations and problems, coordination and communication are well established and effective. But the scale of the COVID-19 crisis and the current turbulence, uncertainty, polymorphism and combination of risks, threats and their consequences create new questions that time will answer. It is also important to emphasize that the effectiveness of such activities ensures the implementation of the National Millennium Development Goals, such as Goal 3 for health and well-being, Goal 17 for partnership for the future.

The state and the health care system responded to this challenge according to the assessment of the real situation in the country and the experience and scientific findings of other countries of the world. By the Resolution of the Cabinet of Ministers of Ukraine No. 211 (dated March 11, 2020) "On Preventing the Spread of COVID-19 Coronavirus in Ukraine", quarantine was introduced for the period from $03 / 12 / 2020$ to $04 / 03 / 2020$. [2, 3]

We emphasize that the beginning of this epidemic and the introduction of quarantine in Ukraine has complex and ambiguous economic and social conditions such as hostilities in the east of the country, political uncertainty and dissatisfaction of a significant part of the population with the decisions and actions of the country's leadership, including the use of quarantine measures. After years of political and economic tension, the Ukrainian economy had started stabilizing, but the outbreak of COVID-19 reversed this trend. Unfortunately, poverty is not the main problem for the state of Ukraine and its citizens. As the largest country in Europe, Ukraine has one of the lowest GDP per capita in the region, surpassing only Moldova in this indicator. Such data are provided by the IMF [4]. Overcoming poverty is one of the most important tasks of the country's strategic development. However, in 2020, Ukrainians became even poorer, because the overwhelming majority of Ukrainian families felt financial difficulties during the crisis and pandemic: in 2019 , the country as a whole earned 3.97 trillion hryvnia, while the annual GDP per ordinary Ukrainian amounted to 94,590 hryvnia, as Ukrstat reports. In 2020, Ukrainian GDP decreased by $5-7.7 \%$, according to preliminary data from the Ministry of Finance of Ukraine, the World Bank and the IMF. During the pandemic, not only money decreased, but also - almost every tenth able-bodied citizen is unemployed, although last year only one in twelve was unemployed. Optimistic that the average salary has grown, however, it did not exceed the level which was in December 2019 , and this will be offset by taking into account inflation. Significant negative consequences in small entrepreneurs, the number of which has not changed during the year of the pandemic, a third of them need government assistance, because in 2020 they suffered high losses due to quarantine (they note a loss of $50-75 \%$ of income and an increase in debt) and a lack of financial reserves of $86 \%$ of individual entrepreneurs, according to a survey of the European Business Association. This will affect everyone's ability to stay healthy and take effective care of their own, individual, and public health. As a result, the activity of appeals and quality medical care are in question.

According to NBU, 70\% of companies reported a decline in sales and earnings. The largest losses were incurred by the industries associated with retail trade, transport and services sector [5].

For healthcare in 2020, it was assumed 113 billion UAH, which is 13\% more than the budget of 2019 [6].

On April 13, the Verkhovna Rada of Ukraine at an extraordinary plenary meeting approved the changes in the State Budget for 2020 by forming the Fund for Combating Acute Respiratory Disease COVID-19 caused by the SARS$\mathrm{CoV}-2$ coronavirus and its consequences. The volume of the fund amounted to 64.7 billion UAH.

The finances of the fund were to be directed to prevent the emergence and spreading epidemics, helping to localize and liquidate an outbreaks of epidemy of acute respiratory disease COVID-19. Also fund included additional salaries to medical and other workers, providing financial assistance to citizens affected by the consequences of the spread of coronavirus disease, assistance in case of unemployment due to epidemic etc [7].

As of September 15, 2020, UAH 65.4 billion has been allocated from the Fund, which is $99 \%$ of its total amount. Only $24.7 \%$ of the allocated funds were directed to the healthcare sector. A significant share of funds (UAH 26.18 billion) was allocated for the reconstruction and repair of highways of national importance, which is almost $40 \%$ of the fund [8]. Such distribution of funds may be regarded as inappropriate.

Despite all the quarantine restrictions and the creation of a special fund, the incidence of coronavirus continued to rise: from 833 confirmed cases in March to 97935 cases in Nowember 2020. After Nowember 28 number of cases begin to decrease. [9]

Dynamics of COVID-19 morbidity and mortality is represented in table 1 . As can be seen from the data, indicators grew rapidly from May to December 2020.Since the beginning of 2021, the dynamics of the increase in the incidence rate has slowed down [10]. 
Table I. Dynamics of COVID-19 morbidity and mortality

\begin{tabular}{cccc}
\hline & Total confirmed cases (thousands) & Total recovered (thousands) & Total death \\
\hline May 2020 & 15,94 & 4,7 & 424 \\
\hline August 2020 & 85,18 & 56,49 & 2006 \\
\hline December 2020 & 897,63 & 606,29 & 15990 \\
\hline February 2021 & 1250 & 1080 & 23770 \\
\hline
\end{tabular}

According to data on "Official information portal of the Cabinet of Ministers of Ukraine» the average supply of hospitals with medical equipment in April 2020 was at $73,35 \%$, average provision of personal protective equipment for medical staff was $57 \%$. Provision of hospitals with medical staff ranged from $58,13 \%$ (Luhansk region) to $92,45 \%$ (Rivne region). In December 2020 the average supply of hospitals with equipment decreased to $32,9 \%$, average provision of personal protective equipment for medical staff increased to $67,5 \%$. Provision of hospitals with medical staff ranged from $85,56 \%$ (Chernihiv region) to 94\% (Kherson region) [11]. Based on the above mentioned data, it can be concluded that the anti-epidemic and economic measures were not sufficiently effective.

This data refers only to secondary healthcare facilities and does not reflect condition of primary health care during quarantine. There is no available governmental data about provision of primary health care with medical staff, protective and medical equipment.

Primary health care plays a key role in the provision of medical services to the population in emergency situations. Reliable primary health care providers who are well-versed in the health needs of the local population, with proper planning and resources, can find mechanisms to fulfill this important role during emergencies [12].

During epidemic family doctors have been entrusted with additional functions such as differentiating between patients with respiratory symptoms and patients with COVID-19, early diagnosis, helping vulnerable people cope with their concerns about the virus, outpatient management of patients with coronavirus disease and reducing the demand for hospital service, setting up plans for the safe and contained transportation of cases that are to be at the hospitals or other locations etc. [13] The concept of reliability of primary care in a pandemic includes the ability to provide the population with the necessary medical care, rational allocation of human and material resources in outpatient clinics and PHC centers, appropriate infection control procedures, safe onward referral and follow-up observation of patients with confirmed COVID-19 infection.

Despite the increase in workload and changes in working conditions for primary health care doctors, the capital rate for the provision of primary medical care to patients remained at the level of 2019 (taking into account the coefficients) and is about $600 \mathrm{UAH}$ per patient [14]. These conditions negatively affected the quality and availability of health care for the population.

As part of the study of population satisfaction with the quality of medical services at the primary level, respondents were asked to assess the overall impression from the services received. $20.1 \%$ were completely satisfied. $29.2 \%$ were mostly satisfied. $9 \%$ are mostly dissatisfied and $7.6 \%$ are dissatisfied with the quality of the services provided. $11.8 \%$ could not decide on the answer. Also, $34 \%$ of respondents reported that because of restrictions, at least once during the quarantine period, they had to refuse to seek medical help if they felt worse. $39.7 \%$ were unable to pass a routine medical check-up, and another $17 \%$ could not receive a vaccination. $36.9 \%$ of the respondents ignored the symptoms of deterioration of health in order to avoid going to the outpatient clinic. $40.4 \%$ tried to be treated on their own through the difficulties associated with quarantine restrictions in outpatient clinics.

The respondents were asked to assess the changes in the provision of services at the primary care level, which took place in connection with the coronavirus epidemic. $21.7 \%$ reported an improvement in the quality of health care delivery. $27.4 \%$ reported that quality has not changed. $24.5 \%$ of respondents believe that the quality of medical services has deteriorated. $33.7 \%$ could not decide [15].

As part of the anti-crisis strategy in connection with COVID-19, it is important to reformat the work in order to reduce the impact of external factors and potential crises on operational activities in health care. Therefore, medicine began a large-scale movement towards digitalization, online communication and remote management of patients. This fell on shoulders of medical personnel. They have also been affected by quarantine restrictions and the tension of the pandemic situation. However, the medical industry is facing new challenges, most of the available new technologies, digital solutions and process automation have been introduced and actively applied. Healthcare workers were even protected by the possibility of reducing contact with potentially infected patients. A significant improvement in the situation with the provision of medical care to the population can be achieved also with the wider use of telemedicine - undoubtedly appropriate to minimize the risk of COVID-19 transmission, that prevent any direct physical contact, provide ongoing community care for health care providers, and reduce morbidity and mortality from COVID-19 [16]. Data from randomized trials indicate that clinical consultations conducted via video conferencing tend to generate high patient and staff satisfaction. At the same time, there are no significant differences in the course of the disease, while the speed and efficiency of medical care is increased in comparison with the traditional clinic-based care. Also, telehealth minimizing the risk of COVID-19 
transmission and it can prevent any sort of direct physical contact, provide continuous care to the community for health care providers, and reduce morbidity and mortality from COVID-19 $[16,17]$.

We also consider the activity of the created mobile brigades and the provision of their functioning important and effective - protective equipment, the availability of working transport, additional payment for heavy and health-threatening work. This provided many opportunities to stay at home, fulfilling the conditions of quarantine, and to take a test for the detection of coronavirus in the event of a deterioration in health and well-being. This decision has helped preserve people's health, prevent the spread of infection, control the rate of infection and spread of Covid-19 in the country and its individual territories.

The sporadic inadequate provision of personal protective equipment for healthcare workers, which is still relevant in Ukraine, is a negative trend all over the world. However in Ukraine, the problems of interruptions in the availability of gloves, masks and other personal protective equipment are still relevant. One of the main threats is that it is difficult to predict what will end first and will not be available for purchase on the market. A new trend has also emerged among the general public, including health care workers, not to carry out the necessary studies on covid-19 in the case of a minor acute respiratory viral infection. Especially in the presence of a pathognomonic symptom - loss of smell. Under such circumstances, the state does not receive real figures, statistics and will not see the real picture of the flow of Covid-19. And, worst of all, it will not be able to determine the real efficiency and effectiveness of the quarantine measures taken and the functioning of the medical industry, which is critical for the future development of both the healthcare industry and the country as a whole.

The question of quality, public awareness, availability of scientifically grounded information and understanding of the real situation on the problem of COVID-19 incapacitation, its treatment, and, most importantly, effective prevention, remains poorly researched. In addition to this the problem of lack of awareness of the population about the real possibilities of diagnostics, medical care and the need to seek medical care have arisen - what can a citizen expect? What are his rights and responsibilities? Who and how can protect the rights and opportunities of the patient and the doctor in case of problems? Etc. To provide answers to these important and topical questions, it is necessary to develop scientifically based surveys on public awareness and satisfaction and introduce them on a systemic basis throughout the country.

\section{CONCLUSIONS}

The complexity of the socio-political and economic situation in Ukraine and the conduct of hostilities in the east of the country have significantly complicated the fight against the spread of coronavirus in the country. The lack of a clear plan of action at the beginning, prolonged social and political tensions, military conflict and the failure of the health care system due to the incomplete long process of transformation have negatively affected the state's readiness for this emergency.

Lack of experience in combating such epidemics, imperfection of management decisions that were made at the beginning, lack of resources (logistics, finance, personnel) in the field of health care have led to problems in providing medical facilities and excessive workload on medical staff. Negative changes in the indicators of hospital security were observed both at the secondary level - treatment of patients with COVID-19, and the primary level - primary contact with the patient, primary care, prevention measures. In the long run, this will have significant implications for the individual health of those who have not been able to receive quality care, as well as for public health in general. Further research should be carried out on a regular basis and concern both the organization of medical care and educational activities with a survey of citizens and physicians about the effectiveness of the measures taken.

The growth rates and waves of COVID-19 spread also indicate the ineffectiveness of the quarantine measures. Statistics show that the spread of the infection has been restrained by poor public awareness, which has reduced the effectiveness of the quarantine measures taken.

We consider effective mobilizing joint efforts (of the state, business, communities and citizens) to help the health care system overcome the epidemic and preserve the health of the nation. The effectiveness of communications, collaborations was manifested in the ability to curb the spread of this disease and minimize losses. Also positive is the qualitative transition to a new level of application of online opportunities in the national health care system and in the provision of quality medical services.

\section{REFERENCES}

1. Korolchuk 0 . Trends of the public management development in Ukraine. Association agreement: driving integrational changes. Chicago: Accent Graphics Communications. 2019; 72-87

2. Postanova Kabinetu Ministriv pro zapobihannia poshyrenniu na terytorii Ukrainy koronavirusu COVID-19 vid 11 bereznia 2020 r. № 211 [Resolution of the Cabinet of Ministers on the prevention of the spread of the coronavirus COVID-19 on the territory of Ukraine of March 11, 2020 № 211]. https://zakon.rada.gov.ua/laws/show/211-2020\%D0\%BF\#Text. (in Ukrainian).

3. Postanova Kabinetu Ministriv Ukrainy vid 13 zhovtnia 2020 r. № 956 Pro vnesennia zmin do postanovy Kabinetu Ministriv Ukrainy vid 22 Iypnia 2020 r. № 641 [Resolution of the Cabinet of Ministers of October 13,2020 On Amendments to the Resolution of the Cabinet of Ministers of Ukraine Type 22 July 2020 № 641]. https://zakon.rada.gov.ua/laws/ show/956-2020-\%D0\%BF\#Text. (in Ukrainian).

4. International Monetary Fund. World Economic Outlook, October 2020: A Long and Difficult Ascent. https://www.imf.org/en/Publications/WEO/ Issues/2020/09/30/world-economic-outlook-october-2020.

5. Natsionalnyi bank Ukrainy. Infliatsiinyi zvit, lypen 2020 roku [National bank of Ukraine. Inflation Report. July, 2020]. https://bank.gov.ua/ admin_uploads/article/IR_2020-03.pdf?v=4. (in Ukrainian).

6. Ministerstvo okhorony zdorovia Ukrainy. Biudzhet MOZ Ukrainy-2020: priorytety. [Ministry of Health of Ukraine. Budget of the Ministry of Health of Ukraine 2020: priorities]. https://moz.gov.ua/article/news/ bjudzhet-moz-ukraini-2020-prioriteti-. (in Ukrainian). 
7. Zakon Ukrainy Pro vnesennia zmin do Zakonu Ukrainy “Pro Derzhavnyi biudzhet Ukrainy na 2020 rik" [Law of Ukraine On Amendments to the Law of Ukraine "On the State Budget of Ukraine for 2020"]. https:// zakon.rada.gov.ua/laws/show/553-20\#Text . (in Ukrainian).

8. StateWatch. Analiz efektyvnosti vykorystannia koshtiv Fondu borotby z COVID-19-doslidzhennia ta rekomendatsii StateWatch [StateWatch. Analysis of the effectiveness of the use of funds of the Fund to combat COVID-19 - research and recommendations StateWatch]. https:// statewatch.org.ua/publications/analiz-efektyvnoho-vykorystanniakoshtiv-fondu-borot-by-z-covid-19-doslidzhennia-ta-rekomendatsiistatewatch/. (in Ukrainian).

9. World Health Organization (WHO). Coronavirus Disease (COVID-19) Dashboard - Ukraine. https://covid19.who.int/region/euro/country/ ua.

10. Natsionalna sluzhba zdorovia Ukrainy. Operatyvnyi monitorynh sytuatsii dovkola COVID-19 [National Health Service of Ukraine. Operational monitoring of the situation around COVID-19]. https://nszu.gov.ua/edata/dashboard/covid19.

11. Ministerstvo okhorony zdorovia Ukrainy. Koronavirus v Ukraini: Ofitsiinyi informatsinyi portal Kabinetu Ministriv Ukrainy. Analitychni paneli ta vidkryti dani [Ministry of Health of Ukraine. Coronavirus in Ukraine: Official information portal of the Cabinet of Ministers of Ukraine. Analytical dashboards and open data]. https://covid19.gov. ua/analitichni-paneli-dashbordy (in Ukrainian).

12. World Health Organization (WHO). Primary health care and health emergencies: brief.. Geneva:WH0. 2018; 47.

13. World Health Organization (WHO). Regional Office for the Western Pacific. Role of primary care in the COVID-19 response. Manila: WHO Regional Office for the Western Pacific. 2020. Available from: https:// apps.who.int/iris/handle/10665/331921.

14. Kabinet Ministriv Ukrainy. Postanova Pro Deiaki pytannia realizatsii prohramy medychnykh harantii dlia pervynnoi medychnoi dopomohy na 2020 rik vid 18 hrudnia 2018 r. № 1117. [Cabinet of Ministers of Ukraine. Resolution on Some issues of implementation of medical guarantee programs for primary health care for 2020 from December 18, 2018 № 1117]. https://zakon.rada.gov.ua/laws/show/1117-2018\%D0\%BF\#n11. (in Ukrainian).

15. Ivats-Chabina A. Riven zadovolenosti naselennia yakistiu nadannia medychnykh posluh na rivni pervynnoi lanky v period karantynu cherez COVID-19 [The level of satisfaction of the population with the quality of medical services at the primary health care level during quarantine through COVID-19]. Innovative approaches in medicine: collective monograph. Boston: Primedia eLaunch. 2020; 135-136. D0I-10.46299/ ISG.2020.MONO.MED.III.
16. Monaghesh E., Hajizadeh A. The role of telehealth during COVID-19 outbreak: a systematic review based on current evidence. BMC Public Health. 2020;20:1193. doi: 10.1186/s12889-020-09301-4.

17. Greenhalgh T., Wherton J., Shaw S. et al. Video consultations for COVID-19. BMJ 2020;368:m998. doi: https://doi.org/10.1136/bmj. m998.

The paper was performed as a part of R\&amp;D of UzhNU «Medical-demographic and sanitary-epidemiological situation in the Transcarpathian region as a formation factor of the regional public health system», R\&amp;D of NAPA under the President of Ukraine "Formation of National Resilience in Ukraine in the Conditions of Socio-Economic Turbulence».

\section{ORCID and contributionship:}

Anna R. Ivats-Chabina: 0000-0002-8280-8374 A, B, C, D

Olena L. Korolchuk: 0000-0003-3336-3310 A, E, D, F

Alexandr Yu. Kachur: 0000-0002-1650-4532 D, F

Vladyslav A. Smiianov: 0000-0002-4240-5968 C, D

\section{Conflict of interest:}

The Authors declare no conflict of interest.

\section{CORRESPONDING AUTHOR \\ Olena L. Korolchuk \\ Uzhorod National University \\ 3Narodna Square, 88000 Uzhhorod, Ukraine \\ tel: 0993839955 \\ e-mail: olena.korolchuk@uzhnu.edu.ua}

Received: 22.01 .2021

Accepted: 02.04 .2021

\footnotetext{
A - Work concept and design, B - Data collection and analysis, C - Responsibility for statistical analysis, D-Writing the article, $\mathbf{E}$-Critical review, $\mathbf{F}$ - Final approval of the article
} 